\title{
Development and Validation of Stability Indicating HPTLC and HPLC Methods for Simultaneous Determination of Telmisartan and Atorvastatin in Their Formulations
}

\author{
Kaliappan Ilango ${ }^{1}$ and Pushpangadhan S. Shiji Kumar ${ }^{2}$ \\ ${ }^{1}$ Department of Pharmaceutical Chemistry, S.R.M. College of Pharmacy, S.R.M. University, Kattankulathur, \\ Kancheepuram, Tamil Nadu 603 203, India \\ ${ }^{2}$ Department of Pharmaceutical Chemistry, Jamia Salafiya Pharmacy College, Malappuram, Kerala 673 637, India \\ Correspondence should be addressed to Pushpangadhan S. Shiji Kumar; shijikps@gmail.com
}

Received 29 May 2013; Revised 1 August 2013; Accepted 3 August 2013

Academic Editor: Irene Panderi

Copyright (C) 2013 K. Ilango and P. S. Shiji Kumar. This is an open access article distributed under the Creative Commons Attribution License, which permits unrestricted use, distribution, and reproduction in any medium, provided the original work is properly cited.

\begin{abstract}
The present study describes development and subsequent validation of stability indicating HPLC and HPTLC methods for simultaneous estimation of Telmisartan (TLM) and Atorvastatin (ATV) in their combined formulation. The proposed RP-HPLC method utilizes a Phenomenex Luna $\mathrm{C}_{18}$ column using acetonitrile: $0.025 \mathrm{M}$ ammonium acetate $(38: 52 \%, \mathrm{v} / \mathrm{v})$ as mobile $\mathrm{phase}(\mathrm{pH}$ 3.8), flow rate of $1.0 \mathrm{~mL} / \mathrm{min}$. Quantification was achieved with UV detection at $281 \mathrm{~nm}$ over concentration range of 12 to $72 \mu \mathrm{g} / \mathrm{mL}$ for TLM and 3 to $18 \mu \mathrm{g} / \mathrm{mL}$ for ATV respectively. In HPTLC, separations were performed on silica gel $60 \mathrm{~F}_{254}$ using toluenemethanol-ethyl acetate-acetic acid $(5: 1: 1: 0.3, \mathrm{v} / \mathrm{v})$ as mobile phase. The compact bands of TLM and ATV at $R_{f} 0.37 \pm 0.02$ and $0.63 \pm 0.01$ respectively were scanned at $279 \mathrm{~nm}$. Linear regression analysis revealed linearity in the range of 40 to $240 \mathrm{ng} / \mathrm{band}$ for TLM and 10 to $60 \mathrm{ng} / \mathrm{band}$ for ATV respectively. For both the methods, dosage form was exposed to thermal, photolytic, acid, alkali and oxidative stress. The methods distinctly separated the drugs and degradation products even in actual samples. In conclusion, the proposed HPLC and HPTLC methods were appropriate for routine quantification of TLM and ATV in tablet formulation.
\end{abstract}

\section{Introduction}

Telmisartan, chemically $4^{\prime}-\left[\left(1,4^{\prime}\right.\right.$-Dimethyl-2' -propyl- $\left[2,6^{\prime}-\right.$ bi-[1H]-benzimidazol]-1'-yl) methyl]-[1,1'-biphenyl]-2-carboxylic acid, is a nonpeptide angiotensin-II receptor antagonist which selectively and insurmountably inhibits angiotensin-II $\mathrm{AT}_{1}$ receptor subtype without affecting other systems involved in cardiovascular regulation (Figure 1(a)). Atorvastatin chemically $\left[\mathrm{R}-\left(\mathrm{R}^{*}, \mathrm{R}^{*}\right)\right]-2-(4$-Fluorophenyl)- $\beta$, $\delta$-dihydroxy-5-(1-methylethyl)-3-phenyl-4-[(phenylamino)carboxyl]-1H-pyrrol-1-heptanoic acid calcium salt is a second generation synthetic 3-hydroxy-3-methylglutaryl-coenzyme A (HMG-CoA) reductase inhibitor which decreases de novo cholesterol synthesis (Figure 1(b)). ATV decreases the amount of LDL-cholesterol in blood, reduces blood levels of triglycerides, and slightly increases levels of HDL-cholesterol
[1-3]. The literature survey reveals several methods for determination of TLM and ATV individually in biological fluids and formulation like HPLC and TLC-densitometric and derivative spectrophotometry [4-16]. HPLC and HPTLC methods were reported for the determination of TLM and ATV in combination $[17,18]$.

None of the reported analytical procedures described a stability indicating method for simultaneous determination of TLM and ATV in presence of their degradation products. Hence, the present study was aimed to establish inherent stability of TLM and ATV through stress induced studies under a variety of ICH recommended test conditions [19] and to develop stability indicating HPLC and HPTLC methods. Validation of the developed method was carried out as per ICH guidelines [20]. The developed methods were applied to two marketed tablet dosage forms. 


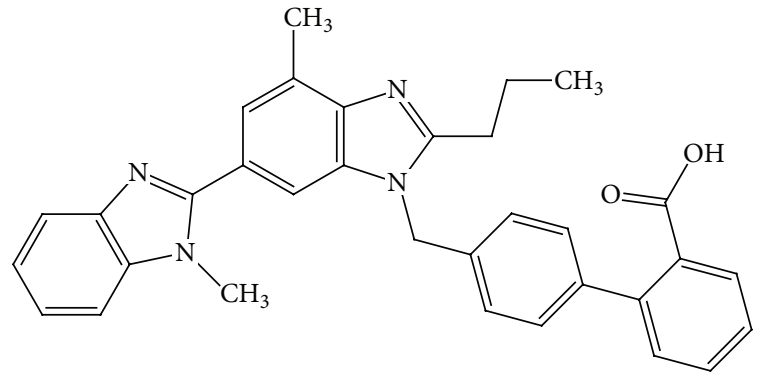

(a)

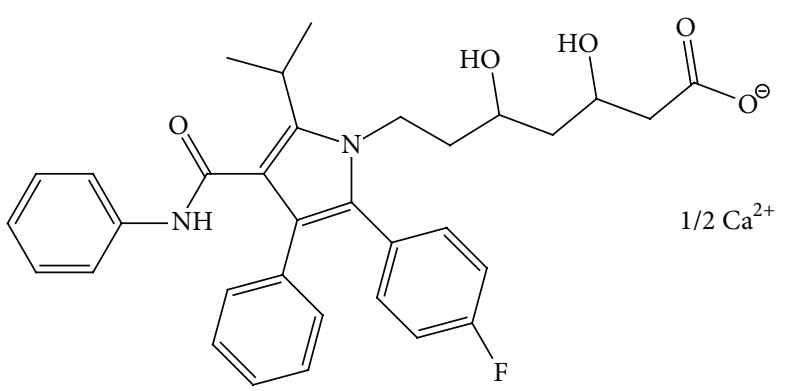

(b)

FIgURE 1: The chemical structure of (a) Telmisartan and (b) Atorvastatin calcium.

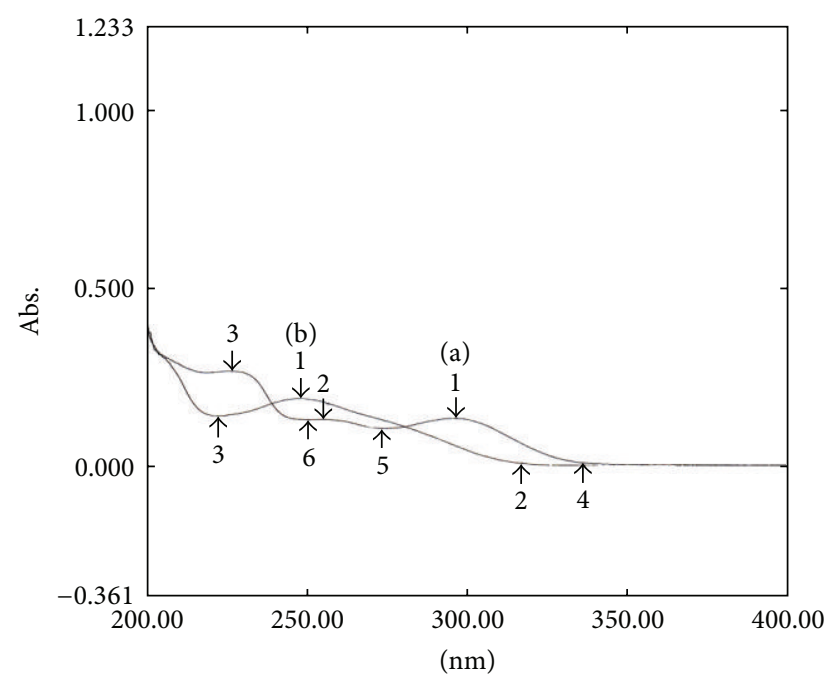

FIgURE 2: Typical overlaid UV spectra of (a) TLM and (b) ATV.

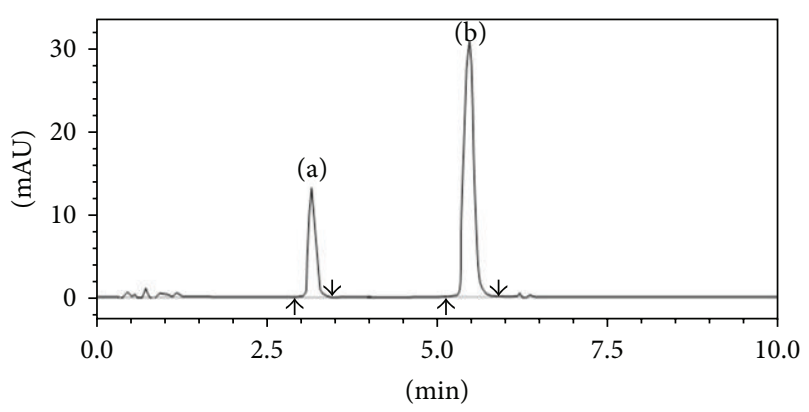

Figure 3: Chromatogram obtained from ATV (Rt 3.21) and TLM (Rt 5.40) at $281 \mathrm{~nm}$.

\section{Experimental}

2.1. Materials and Chemicals. Telmisartan and Atorvastatin were provided by Atoz Laboratories, Chennai, India. Tablets, Telsartan-ATR (Dr. Reddy's Laboratories Ltd., Hyderabad, India) and Arbitel-AV (Micro Labs Ltd., Bangalore, India) both labelled to contain $40 \mathrm{mg}$ TLM and $10 \mathrm{mg}$ ATV, were purchased from local market. Analytical grade methanol, toluene, ethyl acetate, and acetic acid (97 to 98\%, v/v) were obtained from M/S. Merck, Mumbai, India. HPLC grade acetonitrile, ammonium acetate, and acetic acid were obtained from M/S. Merck, Mumbai, India.

2.2. Instrumentation. The HPLC system consisted of a pump (Shimadzu LC 10 ATVP) with $20 \mu \mathrm{L}$ Rheodyne injector, Phenomenex Luna $\mathrm{C}_{18}(5 \mu \mathrm{m} \times 25 \mathrm{~cm} \times 4.6 \mathrm{~mm}$ id $)$ column, and SPD-10 AVP photodiode array (PDA) UV-visible detector set at $281 \mathrm{~nm}$ and equipped with CLASS-VP software (Shimadzu, Kyoto, Japan). In HPTLC, chromatographic separation of drug was performed with silica gel $60 \mathrm{~F}_{254}$ $(10.0 \times 10.0 \mathrm{~cm}$ with $250 \mathrm{~mm}$ layer thickness $)$ from E. Merck, Germany. Samples were applied as $8 \mathrm{~mm}$ bands by means of Camag $100 \mu \mathrm{L}$, sample syringe (Hamilton, Switzerland) with Linomat 5 applicator (Camag, Switzerland). Densitometric scanning was performed in the absorbance/reflectance mode at $279 \mathrm{~nm}$ using Camag TLC scanner 3 with deuterium source, slit dimension settings of length $2 \mathrm{~mm}$, width $0.1 \mathrm{~mm}$, monochromator band width $30 \mathrm{~mm}$, and scan rate of $4 \mathrm{~mm} \mathrm{~s}^{-1}$. Win CATS software (V 1.4.2, Camag, Switzerland) was used for scanner control and data processing.

2.3. Preparation of Standard Solution. For HPLC, individual stock solutions of TLM $(100 \mu \mathrm{g} / \mathrm{mL})$ and ATV $(100 \mu \mathrm{g} / \mathrm{mL})$ were prepared by transferring $10 \mathrm{mg}$ each of TLM and ATV standard in separate $100 \mathrm{~mL}$ volumetric flasks, dissolved in $50 \mathrm{~mL}$ of acetonitrile and made up to volume using the same. From this, suitable dilutions was made using acetonitrile to obtain mixture of solution containing 12 to $72 \mu \mathrm{g} / \mathrm{mL}$ of TLM and 3 to $18 \mu \mathrm{g} / \mathrm{mL}$ of ATV, respectively. Aliquots $(20 \mu \mathrm{L})$ of each solutions were injected and chromatographed in replicate. For HPTLC, standard stock solution was prepared separately by dissolving accurately weighed $10 \mathrm{mg}$ each of TLM and ATV in $100 \mathrm{~mL}$ methanol. From this stock solutions, suitable dilution was made using methanol to obtain a combination solution containing TLM ( 40 to $240 \mu \mathrm{g} / \mathrm{mL}$ ) and ATV $(10$ to $60 \mu \mathrm{g} / \mathrm{mL}$ ) taking into consideration their ratio $(4: 1)$ present in combined tablet formulation.

2.4. Preparation of Sample Solution. Twenty tablets from each brand of one batch were accurately weighed; their mean weight was determined and powdered using glass mortar. For HPLC, an amount of powder equivalent to $50 \mathrm{mg}$ TLM was 
TABLE 1: Data for calibration graphs and system suitability $(n=3)$.

\begin{tabular}{|c|c|c|c|c|}
\hline \multirow{2}{*}{ Parameter } & \multicolumn{2}{|c|}{ RP-LC } & \multicolumn{2}{|c|}{ HPTLC } \\
\hline & TLM & ATV & TLM & ATV \\
\hline Linearity range & $12-72 \mu \mathrm{g} / \mathrm{mL}$ & $3-18 \mu \mathrm{g} / \mathrm{mL}$ & $40-240 \mathrm{ng} / \mathrm{band}$ & $10-60 \mathrm{ng} / \mathrm{band}$ \\
\hline Regression equation & $y=170.7 x+13241$ & $y=340.2 x+1875$ & $y=25.98 x+15.33$ & $y=217.6 x+1845$ \\
\hline Slope & 1.1134 & 1.1376 & 0.9702 & 0.8021 \\
\hline Intercept & 0.9871 & 1.0950 & 1.1000 & 1.4422 \\
\hline Correlation coefficient $(r)$ & 0.9999 & 0.9992 & 0.9998 & 0.9994 \\
\hline Limit of detection (LOD) & $3.21 \mu \mathrm{g} / \mathrm{mL}$ & $1.21 \mu \mathrm{g} / \mathrm{mL}$ & $8.02 \mathrm{ng} / \mathrm{band}$ & $2.13 \mathrm{ng} / \mathrm{band}$ \\
\hline Limit of quantification (LOQ) & $8.65 \mu \mathrm{g} / \mathrm{mL}$ & $2.25 \mu \mathrm{g} / \mathrm{mL}$ & $26.72 \mathrm{ng} / \mathrm{band}$ & $6.22 \mathrm{ng} / \mathrm{band}$ \\
\hline \multicolumn{5}{|l|}{ System suitability } \\
\hline Asymmetry & 1.47 & 1.13 & & \\
\hline Number of theoretical plates & 8641 & 3721 & & \\
\hline Capacity factor & 5.67 & 9.73 & & \\
\hline Resolution & 3.158 & - & & \\
\hline Tailing factor & 0.35 & 0.22 & & \\
\hline
\end{tabular}

TLM: Telmisartan; ATV: Atorvastatin.

TABLE 2: Intraday and interday precisions and accuracies by HPLC method.

\begin{tabular}{|c|c|c|c|c|}
\hline \multirow{3}{*}{$\begin{array}{l}\text { Added conc. } \\
(\mu \mathrm{g} / \mathrm{mL})\end{array}$} & \multirow{2}{*}{\multicolumn{2}{|c|}{$\begin{array}{l}\text { Precision studies } \\
\text { Measured conc. }(\mu \mathrm{g} / \mathrm{mL}) \text { mean } \pm \mathrm{SD} ; \% \text { RSD }\end{array}$}} & \multicolumn{2}{|c|}{ Accuracy studies } \\
\hline & & & \multirow{2}{*}{$\begin{array}{l}\text { Theoretical } \\
\text { conc. }(\mu \mathrm{g} / \mathrm{mL})\end{array}$} & \multirow{2}{*}{$\begin{array}{l}\text { Measured conc. }(\mu \mathrm{g} / \mathrm{mL}) \pm \\
\text { SD; } \% \operatorname{RSD}(n=3)\end{array}$} \\
\hline & Intraday $(n=3)$ & Interday $(n=3)$ & & \\
\hline \multicolumn{5}{|l|}{ TLM } \\
\hline 12 & $11.77 \pm 0.94,0.80$ & $11.88 \pm 0.076,0.64$ & 21.6 & $21.45 \pm 0.367,1.71$ \\
\hline 36 & $35.47 \pm 0.386,1.09$ & $35.33 \pm 0.246,0.70$ & 48.0 & $47.56 \pm 0.675,1.42$ \\
\hline 72 & $70.93 \pm 1.024,1.44$ & $70.86 \pm 1.013,1.43$ & 79.2 & $79.26 \pm 0.731,0.92$ \\
\hline \multicolumn{5}{|l|}{ ATV } \\
\hline 3 & $2.98 \pm 0.011,0.37$ & $3.01 \pm 0.031,1.03$ & 5.4 & $5.33 \pm 0.031,0.58$ \\
\hline 9 & $8.86 \pm 0.026,0.29$ & $8.88 \pm 0.066,0.74$ & 12.0 & $11.88 \pm 0.165,1.39$ \\
\hline 18 & $17.76 \pm 0.267,1.50$ & $17.68 \pm 0.237,1.34$ & 19.8 & $20.06 \pm 0.269,1.34$ \\
\hline
\end{tabular}

TLM: Telmisartan; ATV: Atorvastatin.

transferred into $50 \mathrm{~mL}$ volumetric flask. $25 \mathrm{~mL}$ of acetonitrile was added, followed by sonication for $10 \mathrm{~min}$. The contents were restored to room temperature and diluted to volume with acetonitrile to furnish sample stock solution. The solution was filtered using $0.45 \mu \mathrm{m}$ nylon filter paper (Millipore, Milford, USA), and dilutions were made with acetonitrile to obtain a solution of TLM $(40 \mu \mathrm{g} / \mathrm{mL})$ and ATV $(10 \mu \mathrm{g} / \mathrm{mL})$. Suitable dilutions were made to achieve optimum concentration for analysis. For HPTLC, an amount equivalent to label claim of each active ingredient was accurately weighed and transferred into a suitable volumetric flask. The volume was adjusted with methanol, and the resultant solution was sonicated for $15 \mathrm{~min}$ and filtered through $0.45 \mu \mathrm{m}$ nylon filter. From the resulting solution, suitable aliquots were transferred into $100 \mathrm{~mL}$ volumetric flask and completed to volume with methanol to have a final concentration of $120 \mu \mathrm{g} / \mathrm{mL}$ of TLM and $30 \mu \mathrm{g} / \mathrm{mL}$ of ATV, respectively.

2.5. Forced Degradation Studies. To evaluate the stability indicating properties of the developed methods, forced degradation studies were carried out in accordance with $\mathrm{ICH}$ guidelines.

For HPLC, $10 \mathrm{~mL}$ of TLM and $25 \mathrm{~mL}$ of ATV from previously mentioned stock solutions of standard $(100 \mu \mathrm{g} / \mathrm{mL}$ each) were transferred separately into $25 \mathrm{~mL}$ standard flask containing $5 \mathrm{~mL}$ each of $0.1 \mathrm{M}$ hydrochloric acid, $0.1 \mathrm{M}$ sodium hydroxide and $3 \%$ hydrogen peroxide $(\mathrm{v} / \mathrm{v})$, respectively. The mixture was refluxed at $60^{\circ} \mathrm{C}$ for 1 hour and completed to volume with acetonitrile. The resulting solutions were run under optimized chromatographic conditions.

For HPTLC, $5 \mathrm{~mL}$ each of $0.1 \mathrm{M}$ hydrochloric acid, $0.1 \mathrm{M}$ sodium hydroxide, and 3\% v/v hydrogen peroxide solutions was added to $25 \mathrm{~mL}$ volumetric flask containing $3.0 \mathrm{~mL}$ and $0.75 \mathrm{~mL}$ of methanolic stock solutions of TLM and ATV, respectively. The mixture was refluxed at $60^{\circ} \mathrm{C}$ for $30 \mathrm{~min}$ and completed to volume with same solvent. One microlitre of resulting solutions $(120 \mu \mathrm{g} / \mathrm{mL}$ TLM and $30 \mu \mathrm{g} / \mathrm{mL}$ ATV) was spotted as bands to furnish concentration of $120 \mathrm{ng} / \mathrm{band}$ TLM and $30 \mathrm{ng} / \mathrm{band}$ ATV, respectively. In both HPLC and HPTLC, forced degradation studies using $0.1 \mathrm{M}$ hydrochloric acid, $0.1 \mathrm{M}$ sodium hydroxide, and $3 \% \mathrm{v} / \mathrm{v}$ hydrogen peroxide 


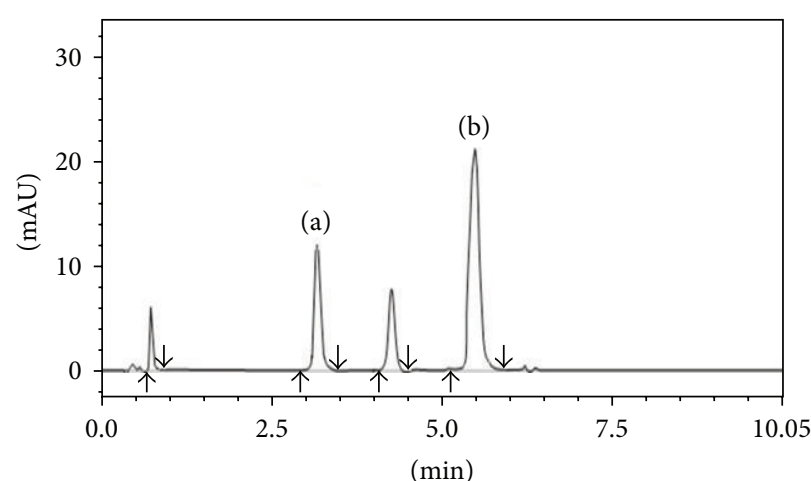

(A)

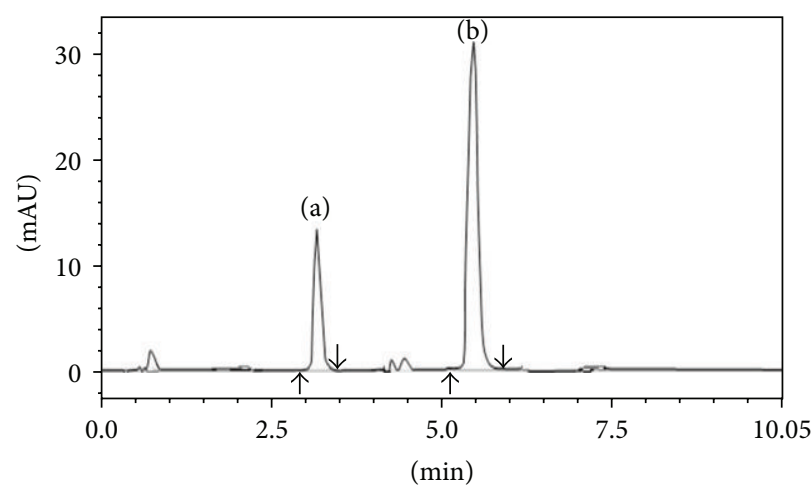

(C)

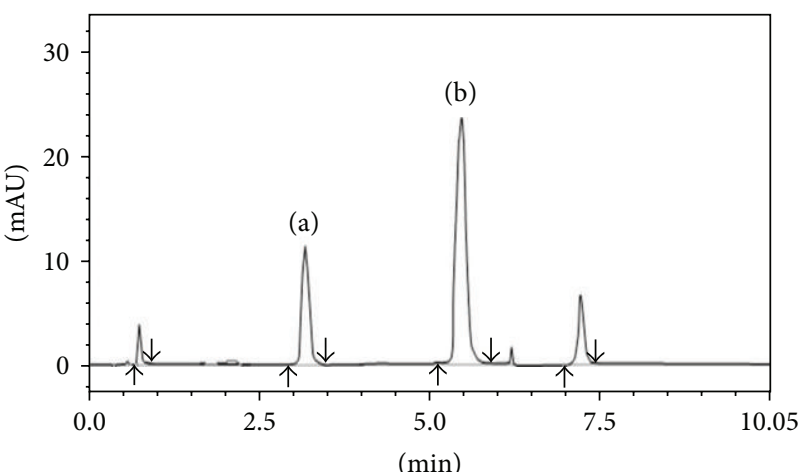

(B)

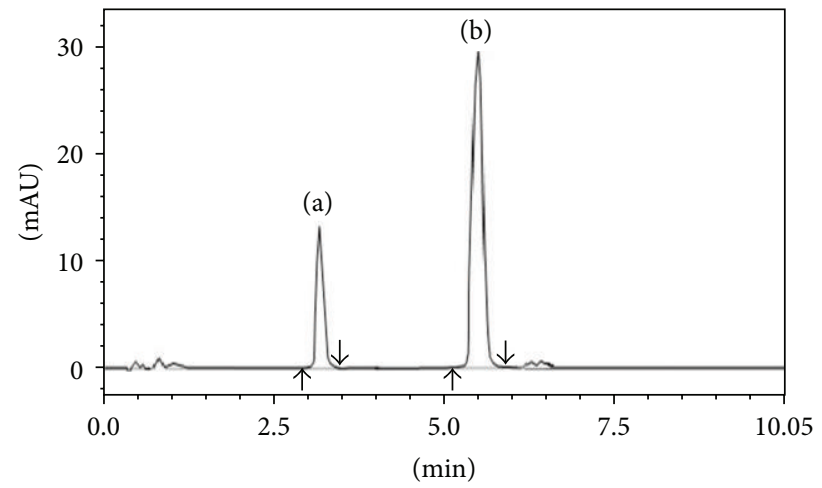

(D)

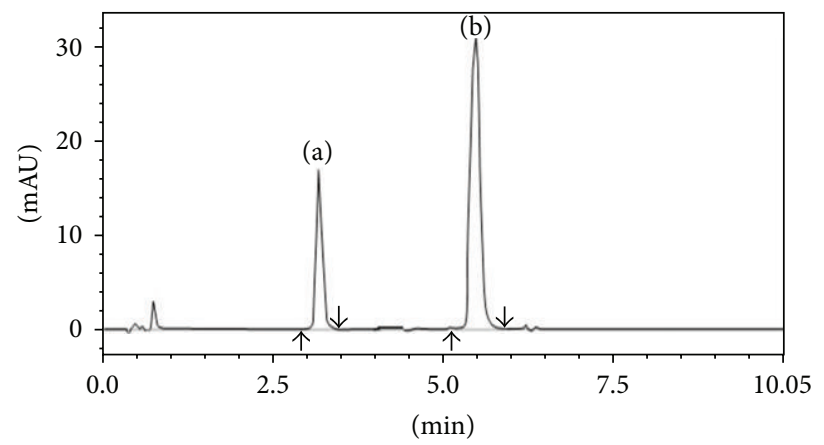

(E)

FIGURE 4: HPLC chromatograms obtained for (a) TLM and (b) ATV from degradation study: showing acid hydrolysis $\left(0.1 \mathrm{M} \mathrm{HCl,} 60^{\circ} \mathrm{C}, 1 \mathrm{hr}\right)$ (A); alkaline hydrolysis $\left(0.1 \mathrm{M} \mathrm{NaOH}, 60^{\circ} \mathrm{C}, 1 \mathrm{hr}\right)(\mathrm{B})$; oxidative degradation $\left(3 \% \mathrm{H}_{2} \mathrm{O}_{2}, 60^{\circ} \mathrm{C}, 1 \mathrm{hr}\right)(\mathrm{C})$; dry heat degradation $\left(60^{\circ} \mathrm{C}, 1 \mathrm{hr}\right)(\mathrm{D})$; and photolytic degradation (UV-chamber, $254 \mathrm{~nm}, 24 \mathrm{hrs})(\mathrm{E})$.

were performed in dark and exclude possible degradation effect of light. Thermal degradation study using HPLC and HPTLC methods was performed by refluxing appropriate dilutions of standards and samples at $60^{\circ} \mathrm{C}$ for 1 hour. The resulting solutions were run under optimized chromatographic conditions. For photodegradation study, appropriate dilutions were exposed to UV light $(365 \mathrm{~nm})$ for 6 hours in UV light chamber. The resulting solutions were analyzed under optimized chromatographic conditions.

\subsection{Method Validation}

2.6.1. Linearity. In case of HPLC, linearity was studied by injecting six concentrations of standard TLM $(12,24,36,48$,
60 , and $72 \mu \mathrm{g} / \mathrm{mL})$ and $\operatorname{ATV}(3,6,9,12,15$, and $18 \mu \mathrm{g} / \mathrm{mL})$ in triplicate. In HPTLC, a series of combination dilutions and standard curves were prepared over a concentration range from 60 to $240 \mathrm{ng} / \mathrm{b}$ and of TLM and 10 to $60 \mathrm{ng} / \mathrm{band}$ of ATV from stock solution. In both methods, peak area versus concentration data was performed by least square linear regression analysis, whereby slope, intercept, and correlation coefficient were determined.

2.6.2. Sensitivity. The sensitivity of the methods was determined with respect to LOD and LOQ. The LOD and LOQ parameters were determined from regression equations of TLM and ATV: $\mathrm{LOD}=3.3 \times \mathrm{SD} / \mathrm{s}, \mathrm{LOQ}=10 \times \mathrm{SD} / \mathrm{s}$, where 
TABLE 3: Results of robustness study by HPLC.

\begin{tabular}{lcc}
\hline \multirow{2}{*}{ Parameter } & TLM & ATV RSD \\
\hline \multicolumn{3}{c}{ Change in pH of mobile phase } \\
$\mathrm{pH} 4.0$ & 0.412 & 0.845 \\
$\mathrm{pH} 3.8$ & 0.850 & 0.567 \\
$\mathrm{pH} 4.2$ & 0.643 & 0.730 \\
\hline \multicolumn{3}{c}{ Change in temperature } \\
$20^{\circ} \mathrm{C}$ & 0.802 & 0.335 \\
$25^{\circ} \mathrm{C}$ & 0.560 & 0.950 \\
$30^{\circ} \mathrm{C}$ & 0.358 & 0.741 \\
\hline \multicolumn{3}{c}{ Change in flow rate } \\
$0.8 \mathrm{~mL} / \mathrm{min}$ & 0.841 & 0.863 \\
$1.0 \mathrm{~mL} / \mathrm{min}$ & 0.924 & 0.857 \\
$1.2 \mathrm{~mL} / \mathrm{min}$ & 1.984 & 1.732 \\
\hline & 0.537 \\
280 & 0.960 & 0.870 \\
282 & Change in wavelength & 1.005 \\
\hline
\end{tabular}

TLM: Telmisartan; ATV: Atorvastatin.

TABLE 4: Results of analysis of tablets.

\begin{tabular}{lcccc}
\hline \multirow{2}{*}{ Method } & \multicolumn{2}{c}{ RP-LC } & \multicolumn{2}{c}{ HPTLC } \\
& TLM & ATV & TLM & ATV \\
\hline Brand I & & & & \\
$\quad$ Label claim (mg/tablet) & 40 & 10 & 40 & 10 \\
\% Mean ( $n=5)$ & 99.56 & 98.42 & 101.07 & 97.80 \\
Standard deviation & 1.1561 & 0.9763 & 0.8913 & 0.6516 \\
Standard error & 1.4132 & 0.7631 & 0.6757 & 0.8318 \\
RSD (\%) & 1.1612 & 0.9920 & 0.8819 & 0.6663 \\
Brand II & & & & \\
Label claim (mg/tablet) & 40 & 10 & 40 & 10 \\
\% Mean ( $n=5)$ & 100.71 & 97.52 & 100.13 & 99.56 \\
Standard deviation & 1.1732 & 0.4897 & 0.7321 & 1.4631 \\
Standard error & 0.1431 & 0.2793 & 0.1896 & 0.5279 \\
RSD (\%) & 1.1649 & 0.5022 & 0.7311 & 1.4696 \\
\hline
\end{tabular}

TLM: Telmisartan; ATV: Atorvastatin.

"SD" is the standard deviation of response and "s" slope of calibration curve.

2.6.3. Precision and Accuracy. Intra- and interday precisions of the methods were determined by performing replicate $(n=3)$ analyses of standards and samples. This procedure was replicated on different days $(n=3)$. Recovery studies by standard addition method were performed in view of justifying accuracy of the proposed methods. Previously analysed samples containing TLM and ATV were spiked with standard TLM and ATV, and the mixtures were analysed in triplicate $(n=3)$ by proposed methods. Precision was calculated from percentage relative standard deviation (RSD \%) for repeated measurements, whereas accuracy was expressed as $\%$ of recovery.

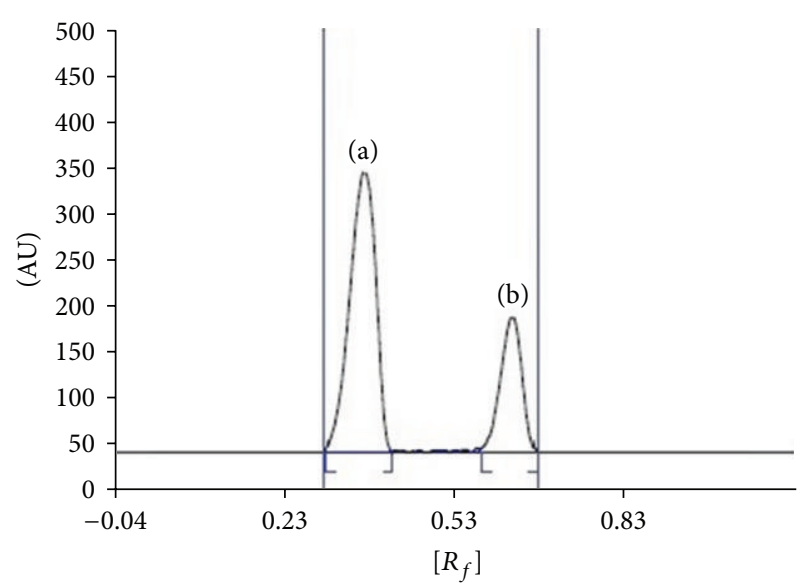

FIGURE 5: Densitogram obtained from TLM $\left(R_{f} 0.37\right)$ and ATV $\left(R_{f} 0.63\right)$ at $279 \mathrm{~nm}$.

TABLE 5: Stability studies by HPLC and HPTLC methods.

\begin{tabular}{lcc}
\hline $\begin{array}{l}\text { Degradation } \\
\text { condition }\end{array}$ & $\begin{array}{c}\text { Number of } \\
\text { degradation products }\end{array}$ & $\begin{array}{c}\text { Area of degradation } \\
\text { product (\%) }\end{array}$ \\
\hline HPLC & 2 & 542,1241 \\
Acid & 2 & 437,985 \\
Base & 1 & 325 \\
Oxidative & - & - \\
Heat & - & - \\
Photo & 2 & $R_{f}$ \\
HPTLC & 4 & $0.27,0.45$ \\
Acid & 1 & $0.42,0.58,0.74,0.80$ \\
Base & - & - \\
Oxidative & - & - \\
Heat & & 0.20 \\
Photo & & - \\
\hline
\end{tabular}

2.6.4. Specificity. For HPLC, the specificity of the method was established through study of resolution factor of drug peaks from the nearest resolving peak and also among all other peaks. In HPTLC, the bands for TLM and ATV in sample were identified by comparing $R_{f}$ values and spectrum of band with those of the bands from standard. The peak purity of TLM and ATV was assured by comparing spectra acquired at three different positions on peaks (peak start, apex, and end).

2.6.5. Robustness. Robustness of HPLC method was determined by deliberately varying certain parameters like detection wavelength, temperature, flow rate, and $\mathrm{pH}$ of mobile phase. For HPTLC, the conditions altered were mobile phase composition, development distance, time of spotting, temperature, and detection wavelength. For all changes in conditions, the samples were analysed in triplicate. When the effect altering one set of conditions was tested, the other conditions were held constant at optimum values. 


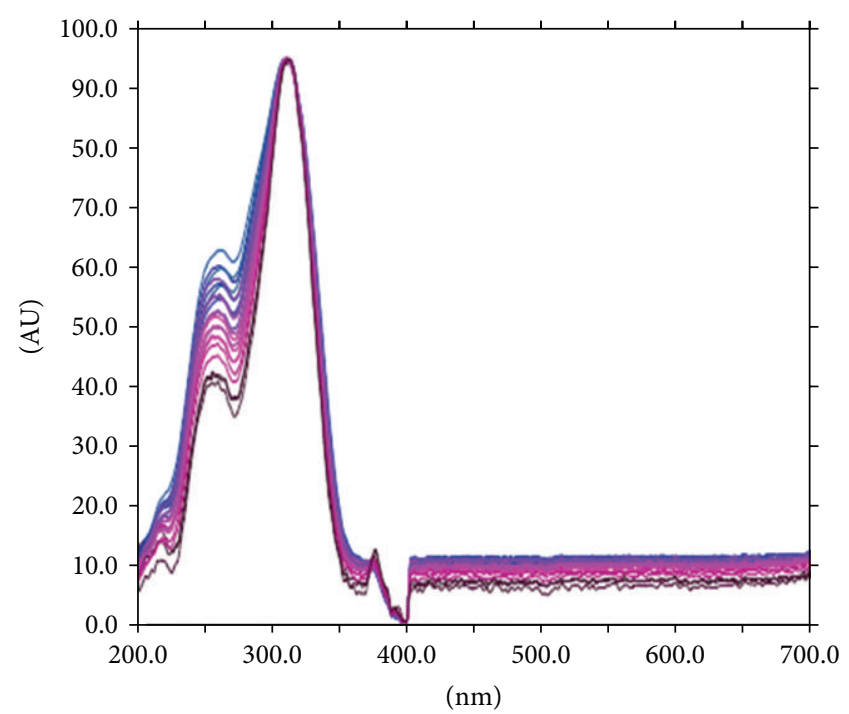

(a)

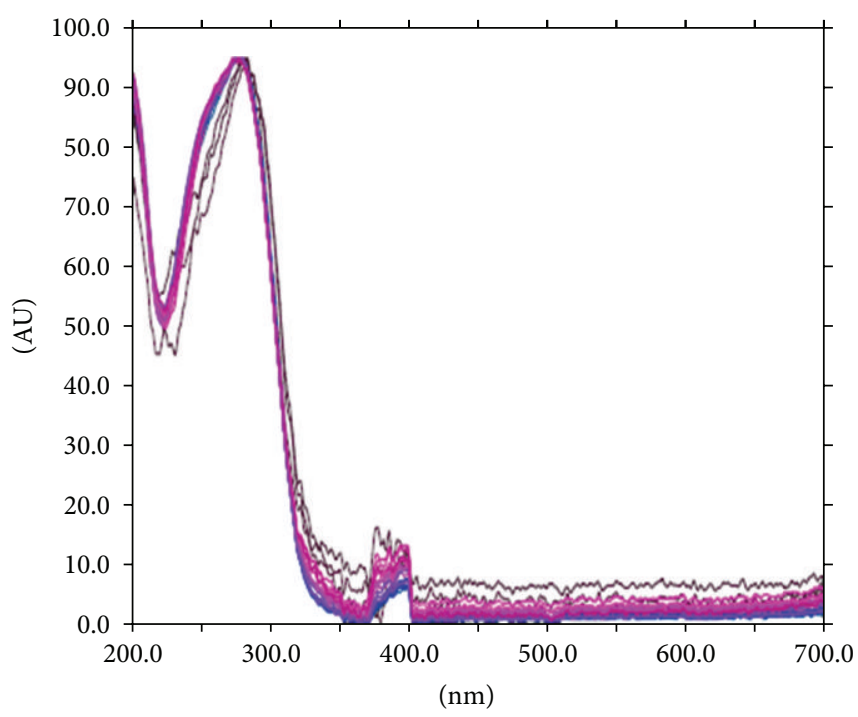

(b)

FIgURE 6: Peak purity spectra of (a) Telmisartan and (b) Atorvastatin.

TABLE 6: Intraday and interday precisions and accuracies by HPTLC method.

\begin{tabular}{|c|c|c|c|c|}
\hline \multirow{3}{*}{ Added conc. (ng/band) } & \multirow{2}{*}{\multicolumn{2}{|c|}{$\begin{array}{c}\text { Precision studies } \\
\text { Measured conc. (ng/band) mean } \pm \text { SD; \% RSD }\end{array}$}} & \multicolumn{2}{|c|}{ Accuracy studies } \\
\hline & & & \multirow{2}{*}{$\begin{array}{l}\text { Added conc. } \\
\text { (ng/band) }\end{array}$} & \multirow{2}{*}{$\begin{array}{l}\% \text { Recovery } \pm \text { SD; } \\
\% \operatorname{RSD}(n=3)\end{array}$} \\
\hline & Intraday $(n=3)$ & Interday $(n=3)$ & & \\
\hline \multicolumn{5}{|l|}{ TLM } \\
\hline 40 & $39.07 \pm 0.27 ; 0.69$ & $38.25 \pm 0.57 ; 1.49$ & 40 & $100.42 \pm 0.47 ; 0.72$ \\
\hline 120 & $120.87 \pm 0.45 ; 0.37$ & $120.16 \pm 0.69 ; 0.57$ & 80 & $99.95 \pm 0.68 ; 0.52$ \\
\hline 240 & $238.89 \pm 0.66 ; 0.28$ & $238.50 \pm 0.51 ; 0.41$ & 120 & $99.57 \pm 0.34 ; 0.18$ \\
\hline \multicolumn{5}{|l|}{ ATV } \\
\hline 10 & $9.88 \pm 0.13 ; 1.32$ & $9.72 \pm 0.16 ; 1.65$ & 10 & $97.86 \pm 0.17 ; 0.50$ \\
\hline 30 & $29.36 \pm 0.54 ; 1.84$ & $29.28 \pm 0.24 ; 1.40$ & 20 & $97.99 \pm 0.49 ; 0.71$ \\
\hline 60 & $59.70 \pm 0.51 ; 0.85$ & $60.08 \pm 0.42 ; 0.70$ & 30 & $98.81 \pm 0.37 ; 0.34$ \\
\hline
\end{tabular}

TLM: Telmisartan; ATV: Atorvastatin.

2.6.6. System Suitability. The system suitability test was performed to confirm that the LC system to be used was suitable for intended application. A standard solution containing $40 \mu \mathrm{g} / \mathrm{mL}$ of TLM and $10 \mu \mathrm{g} / \mathrm{mL}$ of ATV was injected six times. The parameters retention time, resolution, capacity factor, theoretical plates, tailing factor, and \% RSD were determined.

\section{Results and Discussion}

3.1. Reversed Phase High Performance Liquid Chromatography. A satisfactory separation was obtained when using acetonitrile $0.025 \mathrm{M}$ ammonium acetate $(38: 52, \mathrm{v} / \mathrm{v}), \mathrm{pH}$ 3.8 using acetic acid under isocratic conditions, and a flow rate of $1.0 \mathrm{~mL} / \mathrm{min}$. From the overlain spectra (Figure 2), it was observed that the drugs exhibited strong absorbance at $281 \mathrm{~nm}$, which is selected for detection. Peaks were well defined, resolved, and almost free from tailing. Retention times of TLM and ATV were observed at 5.40 \pm 0.02 and $3.21 \pm$ 0.02 , respectively (Figure 3 ), and the optimum wavelength was determined to be $281 \mathrm{~nm}$.

System suitability tests were also carried out to verify reproducibility, and results are summarized in Table 1. For quantitative applications, linear calibration graphs were obtained with correlation coefficients of 0.9991 and 0.9989 for TLM and ATV, respectively. Calibration plots were linear from 12 to $72 \mu \mathrm{g} / \mathrm{mL}$ for TLM and 3 to $18 \mu \mathrm{g} / \mathrm{mL}$ for ATV. Limits of detection (LOD) were $3.21 \mu \mathrm{g} / \mathrm{mL}$ for TLM and $1.21 \mu \mathrm{g} / \mathrm{mL}$ for ATV; limits of quantification (LOQ) were found to be $8.65 \mu \mathrm{g} / \mathrm{mL}$ for TLM and $2.25 \mu \mathrm{g} / \mathrm{mL}$ for ATV which showed good sensitivity of the proposed method. The low RSD $(<2.0 \%)$ values of intraday and interday precision for TLM and ATV revealed that the proposed method is precise (Table 2). \% RSD of recovery study was found to be 0.58 to 1.71, which indicated that the method is accurate (Table 2). Upon slight variation in the selected parameters, insignificant difference in peak area and retention time was observed. 
TABLE 7: Results of robustness study by HPTLC.

\begin{tabular}{|c|c|c|c|c|c|c|}
\hline \multirow{2}{*}{ Condition } & \multicolumn{2}{|c|}{ Retention factor $\left(R_{f}\right)$} & \multicolumn{2}{|c|}{ Assay (\%) } & \multicolumn{2}{|c|}{$\%$ RSD } \\
\hline & TLM & ATV & TLM & ATV & TLM & ATV \\
\hline \multicolumn{7}{|c|}{ Mobile phase composition (v/v) } \\
\hline \multicolumn{7}{|c|}{ Toluene-methanol-ethyl acetate-acetic acid } \\
\hline$(4.9: 1: 1: 0.5)$ & 0.37 & 0.64 & 100.70 & 101.20 & 0.41 & 0.69 \\
\hline$(5: 1: 1.1: 0.4)$ & 0.35 & 0.63 & 99.30 & 100.76 & 1.21 & 1.08 \\
\hline$(5: 1: 0.9: 0.6)$ & 0.35 & 0.63 & 98.72 & 97.91 & 0.93 & 0.86 \\
\hline \multicolumn{7}{|c|}{ Development distance $(\mathrm{cm})$} \\
\hline 6 & 0.36 & 0.64 & 98.76 & 101.21 & 0.71 & 0.19 \\
\hline 7 & 0.36 & 0.64 & 97.86 & 99.30 & 0.27 & 0.87 \\
\hline \multicolumn{7}{|c|}{ Time of spotting to chromatogram ( $\mathrm{min}$ ) } \\
\hline 9 & 0.39 & 0.62 & 98.61 & 99.32 & 1.32 & 1.47 \\
\hline 10 & 0.36 & 0.62 & 100.86 & 101.20 & 1.62 & 0.72 \\
\hline \multicolumn{7}{|c|}{ Detection wavelength (nm) } \\
\hline 275 & 0.38 & 0.63 & 98.71 & 99.41 & 1.01 & 0.43 \\
\hline 280 & 0.39 & 0.62 & 98.76 & 99.37 & 0.37 & 0.86 \\
\hline \multicolumn{7}{|l|}{ Temperature $\left({ }^{\circ} \mathrm{C}\right)$} \\
\hline 55 & 0.37 & 0.64 & 99.35 & 100.67 & 1.22 & 0.92 \\
\hline 65 & 0.37 & 0.63 & 98.71 & 99.14 & 1.07 & 1.13 \\
\hline
\end{tabular}

TLM: Telmisartan; ATV: Atorvastatin.

The resolution between TLM and ATV and its major degradation products were found to be $\geq 2.0$ indicating robustness of LC method (Table 3 ). The assay results for an average of five determinations of two tablets (Telsartan-ATR and Arbitel-AV (40 mg TLM and $10 \mathrm{mg}$ ATV)) were shown in Table 4. The mean assay values were 99.56 and 100.71 for TLM and 98.42 and 97.52 for ATV, respectively. The results of quantitative analysis of tablets indicate that the proposed method can be used for routine quantitative and quality control analysis of TLM and ATV in pharmaceutical dosage forms.

Typical chromatograms obtained following the assay of stressed samples of TLM and ATV show significant degradation in acid (Rt 1.8 and 4.5) and alkali hydrolysis (Rt 1.7 and 7.2). Thermal and photolytic stress conditions show insignificant degradation for TLM and ATV. From the peak purity profile studies, it was confirmed that peak of the degradation product was not interfering with the response of drugs (Table 5). It confirms that, degradation products can be separated from the drugs by this method (Figure 4).

3.2. High Performance Thin Layer Chromatography. Preliminary experiments were carried out to optimise parameters affecting simultaneous estimation of both the drug using HPTLC and detection at $279 \mathrm{~nm}$. Mobile phase consisting of toluene-methanol-ethyl acetate-acetic acid $(5: 1: 1: 0.3$, $\mathrm{v} / \mathrm{v} / \mathrm{v} / \mathrm{v}$ ) was found to give best sensitivity, efficiency, and peak shape. It was observed that at $279 \mathrm{~nm}$ both drugs could be detected simultaneously with no mobile phase interference, good separation, sensitivity, and consistent baseline (Figure 5). It can also be assumed from peak purity spectra (Figure 6) that the method is specific for these components. Under optimum conditions, the retention factors obtained for TLM and ATV were $0.37 \pm 0.02$ and $0.63 \pm 0.01$, respectively.
The calibration plots were linear in the concentration range between 40 and $240 \mathrm{ng} / \mathrm{band}(n=3, r=0.9998)$ for TLM and 10 to $60 \mathrm{ng} / \mathrm{band}(n=3, r=0.9994)$ for ATV, respectively. The LOD and LOQ obtained by this method were 8.02 and $26.72 \mathrm{ng} / \mathrm{band}$ for TLM and 2.13 and $6.22 \mathrm{ng} / \mathrm{band}$ for ATV, respectively. Table 1 shows linearity parameters of calibration curve. The $\%$ RSD values were 0.28 to 1.84 and 0.41 to 1.65 for intra- and interday precisions, respectively (Table 6). Recovery study (Table 6) performed at three different concentrations in triplicate shows good recoveries: 99.57 to $100.42 \%$ for TLM and 97.86 to $98.81 \%$ for ATV, respectively. Results of robustness study are depicted in Table 7 . The retention factor $\left(R_{f}\right)$ and assay (\%) were not significantly affected. RSD (\%) value in all robustness parameter was found to be $<2 \%$. The validated HPTLC method was applied for simultaneous determination of TLM and ATV in commercial tablets. The results as depicted in Table 4 indicate that each drug in tablet corresponds to requirements of label claim. The low RSD value $(<2 \%)$ confirmed the suitability of method for routine analysis of TLM and ATV in pharmaceutical dosage form.

Typical chromatograms obtained following the assay of stressed samples of TLM and ATV show significant degradation in acid (12\% and $8 \%)$ and alkali hydrolysis (15\% and $28 \%)$. TLM and ATV show extra degradation peaks at $R_{f}$ values 0.27 and 0.45 for acid; $0.42,0.58,0.74$, and 0.80 for alkali; and 0.20 for oxidation. Thermal and photolytic stress conditions show insignificant degradation for TLM and ATV. From the peak purity profile studies, it was confirmed that peak of the degradation product was not interfering with the response of drugs (Table 5). It confirms that degradation products can be separated from the drugs by this method (Figure 7). 


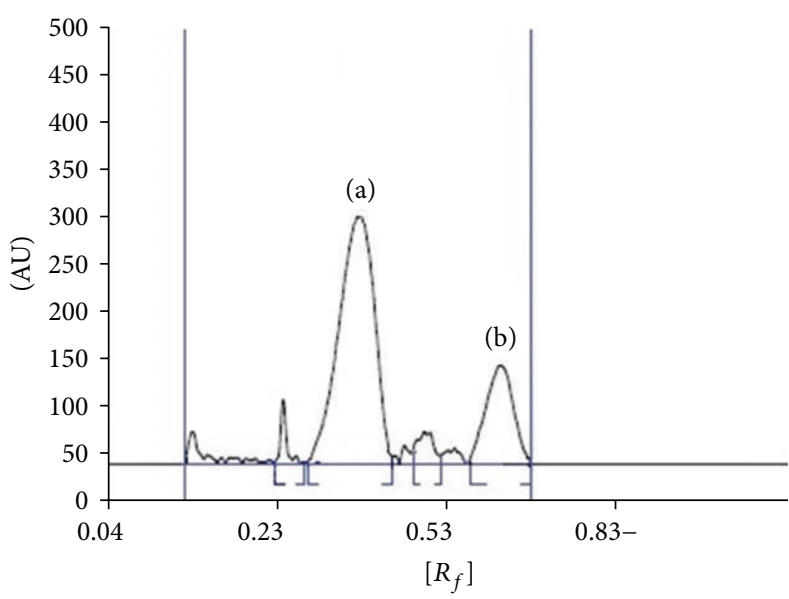

(A)

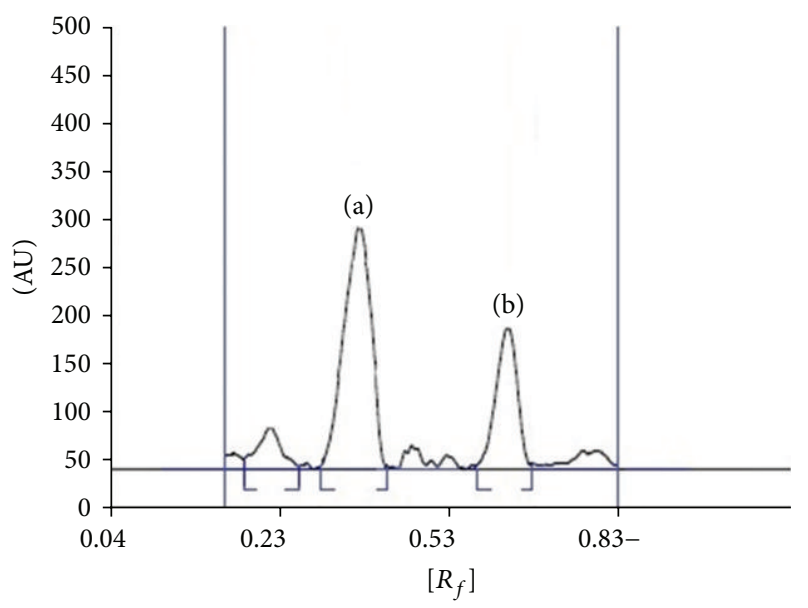

(C)

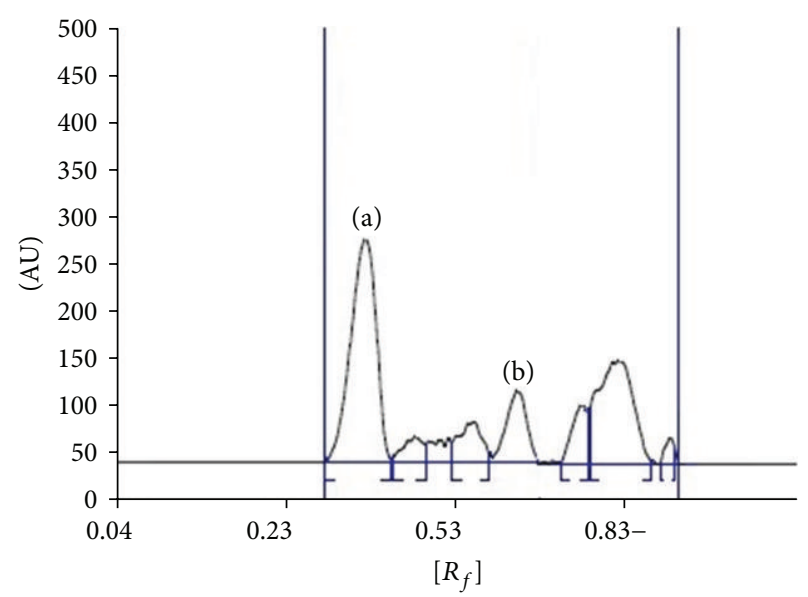

(B)

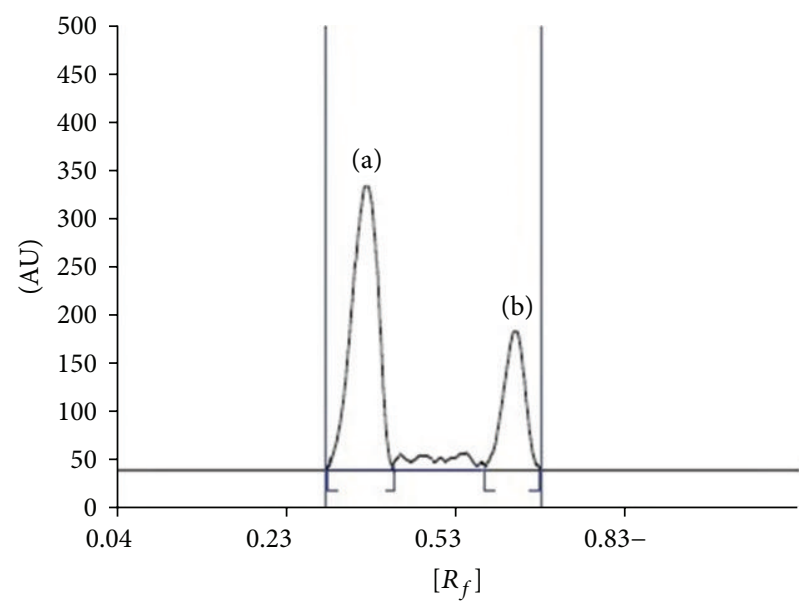

(D)

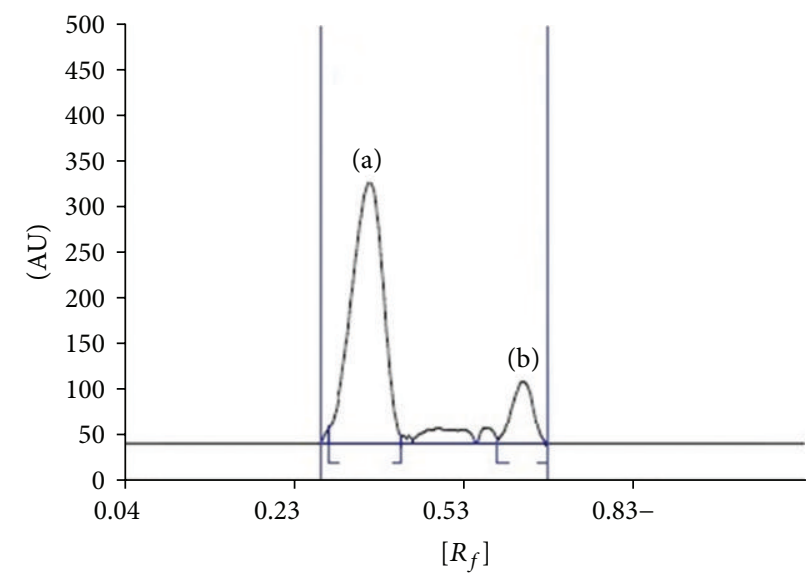

(E)

Figure 7: Chromatograms of (a) TLM and (b) ATV obtained from degradation studies: acid hydrolysis $\left(0.1 \mathrm{M} \mathrm{HCl}, 60^{\circ} \mathrm{C}, 1 \mathrm{hr}\right)(\mathrm{A})$; alkaline hydrolysis $\left(0.1 \mathrm{M} \mathrm{NaOH}, 60^{\circ} \mathrm{C}, 1 \mathrm{hr}\right)(\mathrm{B})$; oxidative degradation $\left(3 \% \mathrm{H}_{2} \mathrm{O}_{2}, 60^{\circ} \mathrm{C}, 1 \mathrm{hr}\right)(\mathrm{C})$; thermal degradation $\left(\mathrm{dry}\right.$ heat, $\left.60^{\circ} \mathrm{C}, 1 \mathrm{hr}\right)(\mathrm{D})$; and photolytic degradation (UV-chamber, $254 \mathrm{~nm}, 24 \mathrm{hrs}$ ) (E).

\section{Conclusion}

The proposed methods were found to be sensitive, reproducible, and accurate for analysis of Telmisartan and Atorvastatin in tablet dosage form. Both methods envisage stability behaviour of Telmisartan and Atorvastatin individually and in combination as per ICH guidelines. Therefore, the proposed methods could be used as stability indicating methods for simultaneous determination of Telmisartan and Atorvastatin in bulk drug and in pharmaceutical formulations. 


\section{Conflict of Interests}

The authors declare that they have no conflict of interests.

\section{References}

[1] A. P. Lea and D. McTavish, "Atorvastatin: a review of its pharmacology and therapeutic potential in the management of hyperlipidaemias," Drugs, vol. 53, no. 5, pp. 828-847, 1997.

[2] L. E. Ramsay, B. Williams, G. D. Johnston et al., "British hypertension society guidelines for hypertension management," British Medical Journal, vol. 319, no. 7210, pp. 630-635, 1999.

[3] K. J. McClellan and A. Markham, "Telmisartan," Drugs, vol. 56, no. 6, pp. 1039-1044, 1998.

[4] T. G. Altuntas and N. Erk, "Liquid chromatographic determination of Atorvastatin in bulk drug, tablets and human plasma," Journal of Liquid Chromatography and Related Technologies, vol. 27, no. 1, pp. 83-93, 2004.

[5] C. Ghosh, I. Jain, S. Gaur, N. Patel, A. Upadhyay, and B. S. Chakraborty, "Simultaneous estimation of atorvastatin and its two metabolites from human plasma by ESI-LC-MS/MS," Drug Testing and Analysis, vol. 3, no. 6, pp. 352-362, 2011.

[6] A. Zarghi, A. Shafaati, S. M. Foroutan, and A. Khoddam, "A simple and rapid HPLC method for the determination of atorvastatin in human plasma with UV detection and its application to pharmacokinetic studies," Arzneimittel-Forschung, vol. 55, no. 8, pp. 451-454, 2005.

[7] M. S. Palled, M. Chatter, P. M. N. Rajesh, and A. R. Bhat, "Difference spectrophotometric determination of telmisartan in tablet dosage forms," Indian Journal of Pharmaceutical Sciences, vol. 68, no. 5, pp. 685-686, 2006.

[8] G. Bahrami, B. Mohammadi, S. Mirzaeei, and A. Kiani, "Determination of atorvastatin in human serum by reversed-phase high-performance liquid chromatography with UV detection," Journal of Chromatography B, vol. 826, no. 1-2, pp. 41-45, 2005.

[9] B. Stanisz and Ł. Kania, "Validation of HPLC method for determination of atorvastatin in tablets and for monitoring stability in solid phase," Acta Poloniae Pharmaceutica, vol. 63, no. 6, pp. 471-476, 2006.

[10] R. N. Rao, K. G. Prasad, C. G. Naidu, and P. K. Maurya, "Development of a validated liquid chromatographic method for determination of related substances of telmisartan in bulk drugs and formulations," Journal of Pharmaceutical and Biomedical Analysis, vol. 56, no. 3, pp. 471-478, 2011.

[11] H. Farahani, P. Norouzi, A. Beheshti, H. R. Sobhi, R. Dinarvand, and M. R. Ganjali, "Quantitation of atorvastatin in human plasma using directly suspended acceptor droplet in liquidliquid-liquid microextraction and high-performance liquid chromatography-ultraviolet detection," Talanta, vol. 80 , no. 2 , pp. 1001-1006, 2009.

[12] R. N. Rao, S. Sen, P. Nagaraju, V. S. Reddy, P. R. Krishnamurthy, and S. U. Bhaskar, "HPLC determination of telmisartan in bulk and pharmaceutical formulations," Asian Journal of Chemistry, vol. 18, no. 2, pp. 775-782, 2006.

[13] G. P. Y. L. Bing, Y. D.-W. Xiao, and X. Wang, "Determination of Telmisartan in human plasma using LC-MS and the concentration of pharmacokinetics and bioavailability study," Chinese Journal of Clinical Pharmacy, vol. 13, no. 4, pp. 200-203, 2006.

[14] C. Hempen, L. Gläsle-Schwarz, U. Kunz, and U. Karst, "Determination of telmisartan in human blood plasma-part II: liquid chromatography-tandem mass spectrometry method development, comparison to immunoassay and pharmacokinetic study," Analytica Chimica Acta, vol. 560, no. 1-2, pp. 41-49, 2006.

[15] K. R. Patil, V. P. Rane, J. N. Sangshetti, and D. B. Shinde, "A stability-indicating LC method for the simultaneous determination of telmisartan and ramipril in dosage form," Chromatographia, vol. 67, no. 7-8, pp. 575-582, 2008.

[16] C. Prabhu, G. S. Subramanian, A. Karthik, S. Kini, M. S. Rajan, and N. Udupa, "Determination of telmisartan by HPTLC-a stability indicating assay," Journal of Planar Chromatography, vol. 20, no. 6, pp. 477-481, 2007.

[17] U. P. Patil, S. V. Gandhi, M. R. Sengar, V. S. Rajmane, and S. V. Gandhi, "A validated densitometric method for analysis of Telmisartan and Atorvastatin calcium in fixed dose combination," Journal of the Chilean Chemical Society, vol. 55, no. 1, pp. 94-96, 2010.

[18] S. C. Manoj, G. Abhinav, and R. D. Chakole, "Simultaneous determination of Atorvastatin calcium and Telmisartan in pharmaceutical formulations by reverse phase-high performance liquid chromatography," International Journal of Pharmaceutical Chemistry, vol. 2, no. 1, pp. 1-6, 2012.

[19] ICH Topic, "Q1A (R2), Stability testing of new drug substances and products," in Proceedings of the International Conference on Harmonization, pp. 1-20.

[20] "ICH Harmonized Tripartite Guidelines: Validation of Analytical Procedures: Text and Methodology," Q2 (R1), pp. 1-13, 2005. 

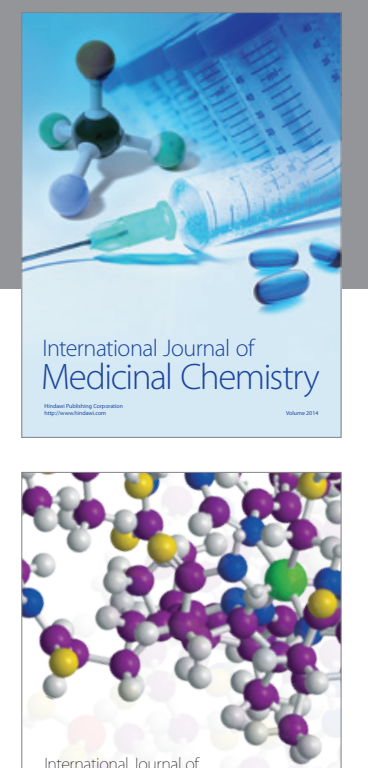

\section{Carbohydrate} Chemistry

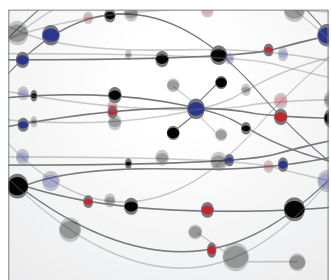

The Scientific World Journal
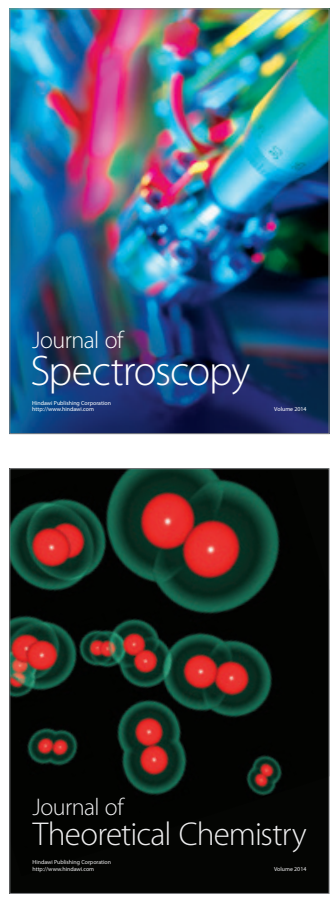
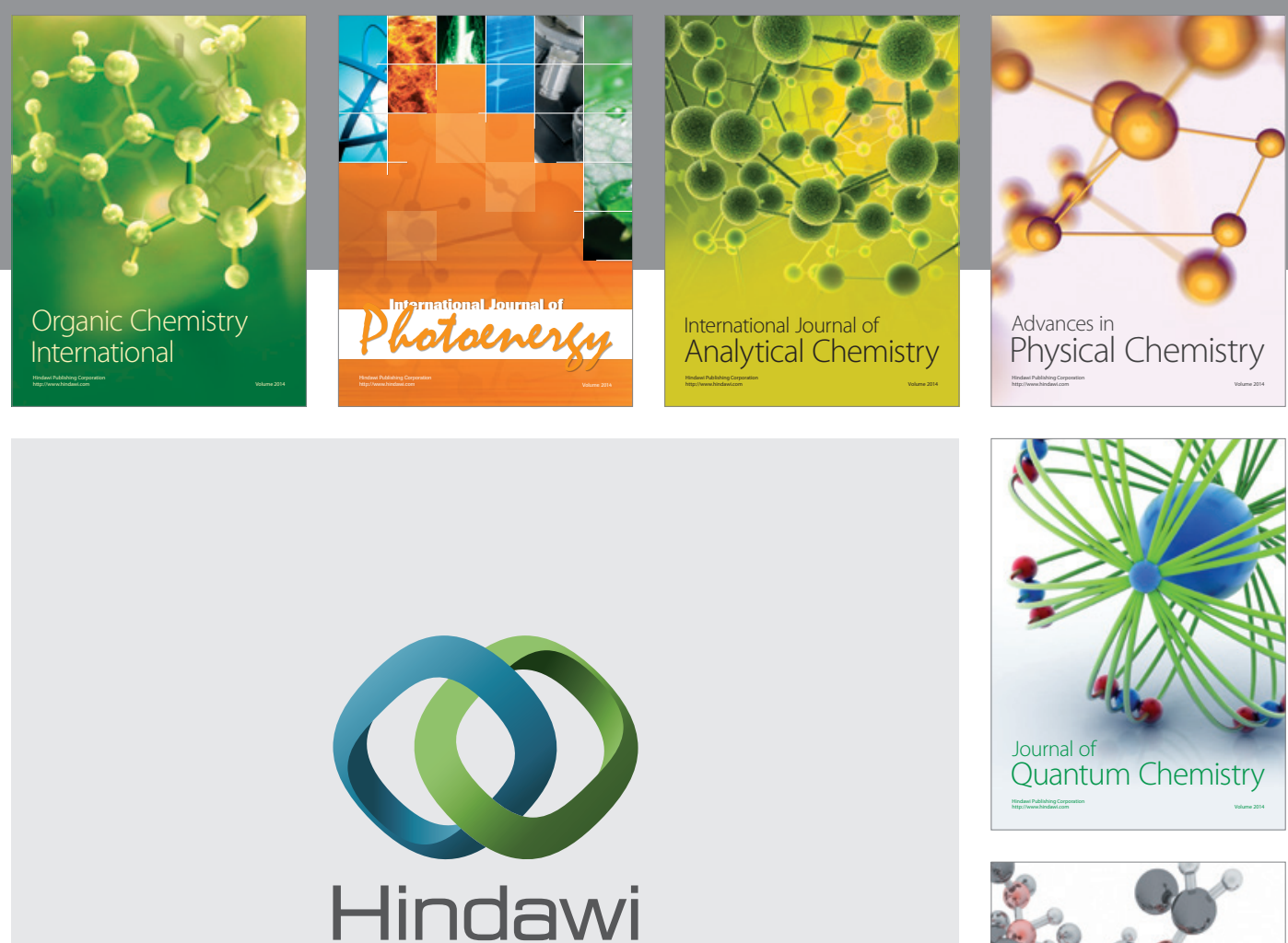

Submit your manuscripts at

http://www.hindawi.com

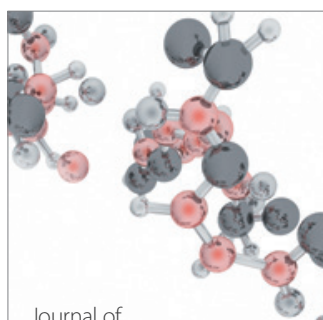

Analytical Methods

in Chemistry

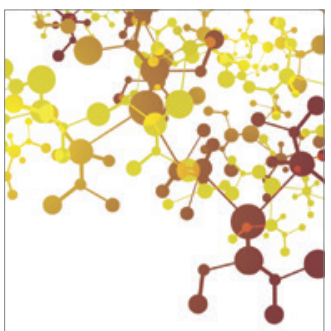

Journal of

Applied Chemistry

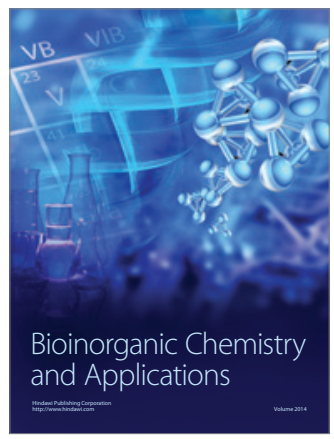

Inorganic Chemistry
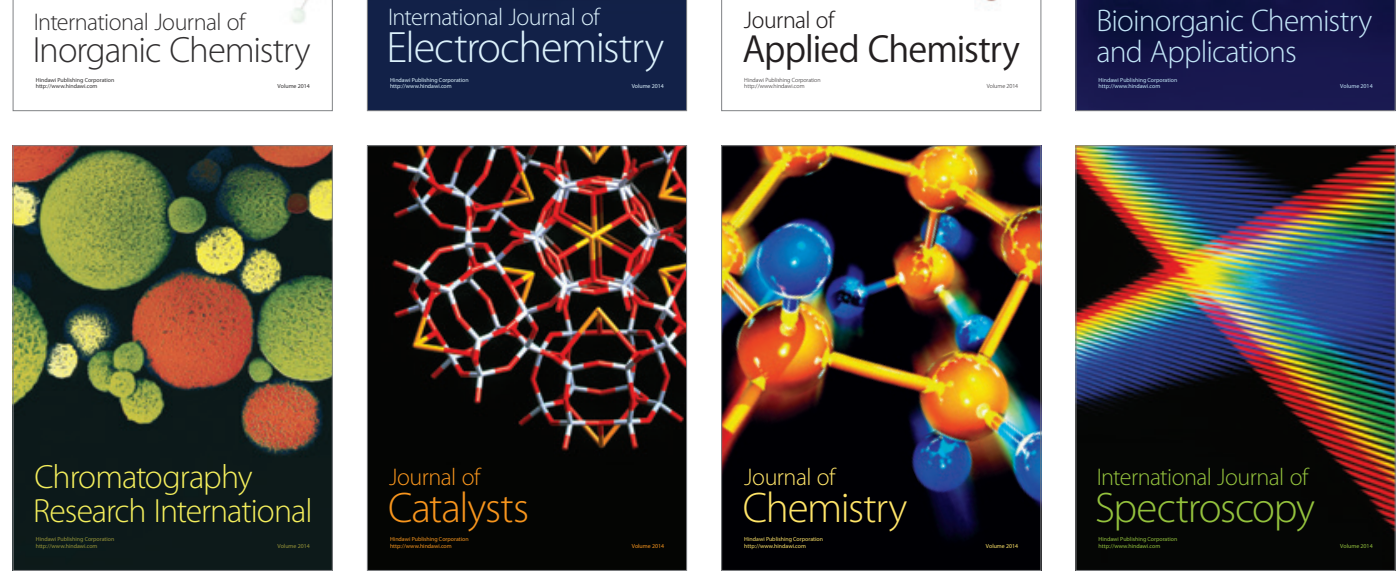